\title{
ESTIMATION OF BASAL HEAT FLUX OVER ICE-COVERED AREAS FROM RADIO ECHO-SOUNDING
}

\author{
By David J. Drewry \\ (Scott Polar Research Institute, Lensfield Road, Cambridge CB2 IER, England)
}

Abstract. Two fundamental boundary conditions for basal ice may be recognized by radio echo-sounding: ice-rock and ice-water interfaces. The latter is identified on the basis of horizontal echoes displaying slow fading, high persistent returned power, and with a reflection coefficient lying between $-\mathrm{I}$ and $-3 \mathrm{~dB}$. Such water, located beneath an ice sheet, provides a known limiting condition to the vertical temperature profile and allows more precise calculation of the basal temperature gradient and estimation of the heat flux through the sole.

Seven sub-ice lakes are located beneath 1.2 to $2.4 \mathrm{~km}$ thick ice inland of the McMurdo dry valleys in Antarctica (Drewry, in press). For each one the temperature profile has been computed from the steady-state solution:

$$
k \frac{\mathrm{d}^{2} T}{\mathrm{~d} z^{2}}-v \frac{\mathrm{d} T}{\mathrm{~d} z}=0
$$

where $T$ is the temperature, $k$ the thermal diffusivity of ice, $v$ the vertical velocity, and $z$ the depth below surface. Horizontal advection has been neglected as the lakes lie close to a centre of outflow and frictional heating will be minimal over an ice/water interface. The profile has been adjusted to the pressure-melting point at the bed in accordance with the presence of water. Heat flux through the base, knowing the thermal conductivity $K_{\mathrm{i}}$ of ice and basal melting $\theta$ is

$$
F_{\mathrm{b}}=\left[\frac{\mathrm{d} T}{\mathrm{~d} z}\right]_{\mathrm{i}} K_{\mathrm{i}}+\theta .
$$

We estimate the heat exchange from melting or freezing assuming the rate to be some reasonable proportion of accumulation (say about $2 \mathrm{~mm} \mathrm{a}^{-1}$ melting). Using surface glaciological data for mean annual accumulation-rate and surface temperature we obtain a value for $F_{\mathrm{b}}$ of 0.08 to 0.1 i W $\mathrm{m}^{-2}$ (2.0-2.7 H.F.U.).

Decker and Bucher (in press) have recently reported temperature gradients and heat fluxes from nearby rock bore holes in the McMurdo dry valleys of 1.9 to 2.5 H.F.U. (o.o8 to $0.10 \mathrm{~W} \mathrm{~m}^{-2}$ ). The close agreement between the computed and observed values of the heat flux suggest that the technique may provide a method of estimating this quantity over large areas of ice sheet devoid of bore holes to bed or exposed rock.

\section{REFERENCES}

Decker, E. R., and Bucher, G. In press. Preliminary geothermal studies in the Ross Island-dry valley region. (In Craddock, C., ed. Antarctic geoscience. Proceedings of the third Symposium on Antarctic Geology and Geophysics, Madison, 22-27 August, 1977. Madison, University of Wisconsin Press.)

Drewry, D. J. In press. Ice flow, bedrock, and geothermal studies inland of McMurdo Sound, Antarctica. (In Craddock, C., ed. Antarctic geoscience. Proceedings of the third Symposium on Antarctic Geology and Geophysics, Madison, 22-27 August, 1977. Madison, University of Wisconsin Press.)

\section{DISGUSSION}

T. J. Hughes: Why doesn't radar sounding detect bottom crevasses underneath ice sheets where subglacial lakes are postulated from radar sounding? Basal extending longitudinal strain-rates should exist in ice entering these lakes just as in ice entering an ice shelf, and basal crevasses are found beneath ice shelves where extending flow occurs. Could the lact of bottom crevasses tell us something about the lake water depth? 
D. J. Drewry: In most cases the dimensions of lakes are small (less than or comparable to ice thickness) so that the analogy with ice-shelf decoupling is not easy. Usually bottom crevasses on ice shelves are visible to radar sounding because frozen brine at the crack tip provides a strong dielectric contrast and a point reflector. Presumably non-saline water beneath the ice sheet might inhibit perception of crevasses at radar frequencies. Their absence in radar records, therefore, cannot be taken as proof that they do not exist.

R. H. Thомas: Presumably any melting or freezing that is taking place at the ice-sheet base will upset your calculations.

DREWRY: Naturally heat added or removed by freezing or melting at the interface has to be taken into account, but unless these zones are untypical of most glacier/ice-sheet beds the heat quantity will not be enormous (in the order of \pm 0.01 to $0.05 \mathrm{~W} \mathrm{~m}^{-2}$ ).

W. D. HARrison: Could one try the opposite approach, assume the heat flow, and estimate the freezing- or thawing-rate at the top of the lake?

Drewry: Certainly this inversion of the problem could be tried where we have a priori knowledge of the heat flux, say from bore-hole measurements into subjacent rock.

R. C. Metcalf: Often in my Caribbean work, one finds abnormal heat flow associated with tectonic activity (faulting) and geothermal activity. Are there indications of these processes in your studies of abnormal heat flow in the Antarctic?

Drewry: The investigated lakes lie close to the exposed Transantarctic Mountains and the McMurdo Cenezoic volcanic zone, with elevated heat flows. The possibility of a failed spreading axis in this region might also suggest enhanced geothermal activity. Lateral heat flushing induced by Australian-Antarctic plate separation is also a possible mechanism and it is interesting to note abnormally high heat flows are reported from south-eastern Australia (o.12 $\mathrm{W} \mathrm{m}^{-2}$ ).

\title{
OBSERVATION OF BASAL SLIDING OF VARIEGATED GLAGIER, ALASKA
}

\author{
By H. Engelhardt, B. Kamb, \\ (Division of Geological and Planetary Sciences, California Institute of Technology, Pasadena, \\ California 9 I 125 , U.S.A.) \\ C. F. RAymond, \\ (Geophysics Program, University of Washington, Seattle, Washington 98195, U.S.A.) \\ and W. D. HARRISON \\ (Geophysical Institute, University of Alaska, Fairbanks, Alaska 9970 I, U.S.A.)
}

Abstract. Variegated Glacier is a surge-type glacier in the St Elias mountain range in Alaska. The interval between surges is about 20 years; the last one occurred in 1964 to 1965 . This glacier has been studied extensively since 1973 (Bindschadler and others, 1977). Thus far, measurements of ice velocities have been restricted to the surface. They have been analyzed using geophysically measured ice depths, in order to estimate ice velocities in the ice mass and at the base (Bindschadler and others, 1978). From 1973 to 1977 the distribution of 